\section{Timothy Cook}

It is with indescribable sorrow that we write with news of the death of our dear friend and colleague, Timothy Cook. Tim passed away from complications associated with brain cancer on August 5, 2006, in Baton Rouge, Louisiana. He was only 51. Tim held the Kevin P. Reilly, Sr. Chair in Political Communication at Louisiana State University.

How does one describe in a few paragraphs a life lived so richly and fully? Tim was an extraordinary person and a wonderful friend and colleague. To be sure, he was a gifted scholar, teacher, and intellectual. Tim was internationally renowned, and his career was marked by his well-recognized contributions to the scholarly literature in several areas of study. But what we will remember the most about Tim is his friendship, as well as his zest for the good things of life. Tim had broad interests that went well beyond the confines of political science. He was as well-read as anyone we know, an aficionado of the arts and culture, and well known for his love of fine food, wine, and the company of his many close friends He was a gentle man, and he treated everyone-even those who did not agree with him-with dignity and respect.

Tim was born on August 16, 1954, in Van Nuys, California. He earned his Bachelor of Arts in government from Pomona College in 1976. After that, his career took him around the country from Wisconsin to Williams College, from Harvard to Louisiana. Tim is survived by his partner of 26 years, Jack Yeager, professor of French Studies at LSU; and his two sisters, Carol Jacoby of Long Beach, California, and Kathy Cook of La Habra, California. The joint hiring of Tim and Jack at LSU was a moment of some historical significance; only rarely has this happened at any institution of higher education in the United States, and we believe it to be only the second time at a university in the South. Tim loved LSU and Louisiana, and the two had planned on spending many years here together.

\section{Career}

Tim received his Ph.D. in political science from the University of Wisconsin in 1982 and began his career with a faculty appointment at Williams College in 1981. Tim had an extraordinary career at Williams, moving quickly through the ranks until his appointment as the Fair- leigh Dickinson, Jr. Professor of Political Science, a chair he held from 1994 to 2002. While at Williams, Tim had visiting appointments at Yale University (spring 1995) and the Kennedy School of Government at Harvard University (spring 1990, and spring 1998 to spring 2000).

In 2002, Tim moved to Louisiana State University as the Reilly Chair in Political Communication. His primary appointment was in the Manship School of Mass Communication, but he also held a joint appointment in the department of political science. Tim immediately took on a leadership role in shaping the development of the political communication program at LSU. He was very active in the Ph.D. program in media and public affairs, involving himself heavily in the school's graduate committee and serving on the committees of several doctoral students. Tim also brought creative thinking and rigor into the classroom, where he was known as an extraordinary teacher. He had high expectations of his students and held them to high standards of excellence, but he was no harsh taskmaster; rather, Tim directed his students in a gentle, nurturing manner, and this made him a superb mentor to students in the Manship program and in the department of political science.

\section{Scholarship}

Tim was an internationally known scholar, with much of his best work coming in the field of media and politics. $\mathrm{He}$ was the author or coauthor of four major books in the field of political communication. His first book, Making Laws and Making News: Media Strategies in the U.S. House of Representatives (Brookings Institution, 1989) was an important study of how House members interact with the news media, particularly in terms of negotiating what is newsworthy. Using data from a variety of sources, he analyzed the media strategies employed by House members to achieve their goals of reelection and policy making. Tim's book is arguably the leading work on congressional-media interactions, and he was recognized for his scholarly accomplishment with the Benjamin Franklin Award from the American Booksellers Association.

His 1996 book, entitled Crosstalk: Citizens, Candidates, and the Media in a Presidential Campaign (University of
Chicago Press) and coauthored with Marion Just, Ann Crigler, Dean Alger, Montague Kern, and Darrell West, was an innovative study of the interplay between candidates, the media, and voters during the 1992 presidential election campaign. Tim and his coauthors developed a compelling constructivist approach to explore the effects of campaign media messages on the opinions of voters, compiling extensive data on the messages of the campaigns in four media markets, and noting how these messages differed across contexts. This book had a major impact on the field of political communication, and was awarded the prestigious Doris Graber Prize in 2003 for the best book published in political communication over the previous 10 years.

Tim wrote a fascinating book, Governing with the News: The News Media as a Political Institution (University of Chicago Press, [1998] 2005), that also received much attention in the literature on media politics. Many political scientists who study political communication focus their research on the effects of the news media on the mass public, but there is considerably less attention paid to the role of the news media as a political institution. Tim was well acquainted and conversant with the literature on the effects of the media on the mass citizenry, but he was first and foremost an institutionalist who viewed the media as a political institution warranting rigorous and systematic study like any of the "traditional" institutions. Governing with the News was a convincing treatment of the news media as a political institution and is sure to draw the attention of political communications scholars well into the future.

The impact of Tim's research extends well beyond the area of political communication. He established a research reputation in at least four other areas of study. First, early in his career Tim published some high-quality work in the area of legislative politics. In 1987, he coauthored an influential paper in the American Journal of Political Science (with Lyn Ragsdale) on the possibility of a reciprocal relationship between the behaviors of House incumbents and challengers, and he also wrote well-regarded articles on public support for Congress and its members and on committee assignments in the U.S. House. By the mid-1980s, Tim also was writing extensively about how members of Congress interact with the media; this was clearly 
a topic close to Tim's heart, since (as we have already noted) this research led Tim to at least two book-length treatments of the subject. Tim's 1986 article in the Legislative Studies Quarterly on news media coverage of House members and Senators was quite innovative and foreshadowed future work on how the news media and legislators interact. He followed this work with an important 1988 article in the American Journal of Political Science on the communication strategies of House members' press secretaries; this work revealed the local focus of activity for most press secretaries but also isolated the effects of variables related to various local and national communication strategies.

Second, Tim developed an early interest in political socialization. His dissertation was on children's literature, and he published a fascinating paper in Polity in 1985 on how children's literature imparts to children important values of the dominant culture. However, in this field Tim is perhaps best known for his important article in the American Political Science Review on the "bear market" in political socialization research. The field of political socialization flourished in the 1960 s and 1970s but began to decline into the 1980s. Tim proposed an interesting theoretical argument about how the field of political socialization could sustain itself and evolve. Although Tim extended his work into other areas of study after the publication of this article, he retained an interest in the field of political socialization until his untimely death. In conversations with LSU colleagues, Tim bemoaned the fact that political socialization no longer held a preeminent place in political science and he looked forward to its rebirth.

Third, Tim was an influential figure in the field of lesbian and gay politics and the politics of AIDS health care. He was a founding member of the Lesbian, Gay and Bisexual Political Science Caucus of the American Political Science Association, and remained active and visible in it throughout his career. Tim was also an innovator and leader in developing courses on the politics of sexual identity virtually everywhere he taught. In 1999, he published an extraordinary review of the "first wave" of empirical research on gay, lesbian, and bisexual politics in the American Political Science Review. Tim noted with disappointment that the study of gays, lesbians, and bisexuals had been left to other disciplines such as sociology and history, but he was encouraged by the new wave of political science research on the subject. The essay was a superlative critical summary that influenced the second wave of scholarly inquiry. While the article is a "must-read" for students of lesbian and gay politics, it is also an important article for any scholar interested in American politics in general. Tim frequently combined his interests in this area with his excellent work on media and politics. He co-authored two book chapters along these lines, one (with Bevin Hartnett) dealing with network news coverage of the politics of the lesbian and gay movement, and another (with David C. Colby) on network news and the politics of the AIDS crisis. He also reviewed several influential works dealing with AIDS, which led to a sidebar interest in other health and public policy works.

Finally, late in his life Tim had embarked on a major project (with his collaborator, Paul Gronke) on trust in government and political institutions. Part of his interest in this broader subject came from his interest in public trust toward the news media, but he quickly broadened his focus to public trust in political institutions in general. In 2005, Tim and Paul published a paper in the Journal of Politics in which they developed new measures of political trust that are better suited to measuring long-term patterns of trust. The two collaborators had begun a book-length treatment of this subject that was interrupted by Tim's untimely death, though Paul Gronke is expected to finish the project.

We would be remiss in discussing Tim's contributions if we did not point out the recognition that he received for his work and the service he gave to the political science profession. Early in his career Tim received the prestigious APSA Congressional Fellowship, and this launched him into some of his best work on the media and Congress. Tim was elected to the council of the American Political Science Association, and he served in that role from 1994 to 1996. He was subsequently elected APSA treasurer, a post that he held from 1997 to 1999, and he followed up his term as treasurer with a term on the APSA Trust and Development Fund from 2000 to 2002. Tim was recognized for his scholarly contributions with appointments to the editorial boards of several leading journals, including the American Political Science Review, American Journal of Political Science, Journal of Politics, Political Communication, Harvard International Journal of Pres/Politics, and Communication Review. His service to the profession was exceptional, but he was placed in these positions of service and responsibility in part because of his strong reputation for scholarly judgment and fairness.

\section{Final Thoughts}

As we noted above, Tim's remarkable career and record is just one part of his invaluable legacy. Perhaps it exemplifies the type of person Tim was: intelligent, committed to excellence, never constrained by the conventional, always curious, intellectually generous, and humble. Tim's first Ph.D. student, Eric Jenner, said at Tim's memorial service last September at LSU, "Tim helped his students see more. He sharpened and broadened our views by talking with us and by caring. He was interested in others. His intelligence was generous." Those of us who knew him well found these same characteristics in Tim outside of the academic world as well. Said one friend after his memorial service, "Tim profoundly touched so many people in many, many ways - his smile, his way with words, his gentle, warm presence, his intelligence and insights, his generosity, caring, and thoughtfulness."

His presence-his truly rare combination of great intelligence and marvelous generosity-will be greatly missed. The Manship School's annual report says it quite nicely, "While he leaves an impressive legacy of vigorous scholarly work, what we will miss most is his friendship. We celebrate his zest for all good things in life."

\section{James C. Garand Louisiana State University Mark Schafer Louisiana State University}

\section{Rita Nealon Cooley}

Professor Rita Nealon Cooley died on October 1, 2006, in her home in New York City. She was born in New York in 1919 and attended a Catholic School in the Bronx where she won the Classics prize and was the Class Valedictorian. After graduating from Hunter College in 1940, cum laude, Phi Beta Kappa, and as winner of the Constitutional Law prize, she was awarded the Penfield Fellowship by the department of politics at NYU in 1943 and began taking courses in the graduate school.

One of her courses, on English history, was taught by the then dean of the graduate school. She received an "A" in the course, as well as in the other four courses she took and was summoned to the dean's office. The dean said to her: "Mrs. Nealon, I think you have the makings of a very good teacher and I want you to help us out by teaching in the history department two sections of the required European history." Rita always said this was the most momentous event 